\title{
The Farmers Perception on Effectiveness of Private Forest Revolving Fund Distribution and Factors Affecting its Repayment: Case in Katibung Subdistrict, South Lampung District, Lampung Province
}

\author{
Sanudin $^{1 *}$, San Afri Awang ${ }^{2}$, Ronggo Sadono², Ris Hadi Purwanto ${ }^{2}$ \\ ${ }^{1}$ Graduate School of Gadjah Mada University, Jl. Agro Number 1 Bulaksumur, Yogyakarta 55281, Indonesia \\ ${ }^{2}$ Faculty of Forestry, Gadjah Mada University, Jl. Agro Number 1 Bulaksumur, Yogyakarta 55281, Indonesia
}

Received January 21, 2016/Accepted March 23, 2016

\begin{abstract}
Commercial banks are not interested in providing fund for community-based forest plantation development. Therefore, in this case, non bank institutions such Forest Development Funding Center (pusat pembiayaan pembangunan hutan, PPPH) are highly required. This paper is aimed to find out the effectiveness of private forest revolving fund distribution and factors affecting its repayment. The research was conducted during September-December 2014 in 3 Private Forest Farmer Groups in Katibung Sub-District, South Lampung District, Lampung Province. The data was collected through household surveys and in-depth interviews. The household surveys were done using structured questionnaires that included questions related to: characteristics of the borrowers, characteristics of private forest, characteristics of loan, and household perceptions on private forest revolving fund. Household perceptions on private forest revolving fund are pre requirement, loan procedure, loan realization, interest rate, length of repayment periode, and repayment procedure. The effectiveness of private forest revolving fund distribution was analyzed by likert scale and factors affecting repayment of loan was analyzed by logistic regression. The result showed that: 1) private forest revolving fund in three private forest farmer groups in Katibung Sub-District, South Lampung District was effective, 2) income from non-private forest and amount of loan are factors affecting repayment of private forest revolving fund, 3) the faced problem in private forest revolving fund distribution could be overcame by maximizing the role of PPPH field officers in assisting and facilitating private forest revolving fund debitors candidate.
\end{abstract}

Keywords: revolving fund, private forest, effectiveness, repayment

*Correspondence author, email: sanevafa2014@gmail.com,ph.+62-81342929991

\section{Introduction}

Most small scale farmers of less developed countries live invicious circle of poverty as they rarely generate income in excess of their consumption requirements that can be saved and used for investment activities (Shakya \& Flinn 1985; Green \& Ng'ong'ola 1993). Lack of access to adequate financial services, especially credit is considered as one of the reasons for rural households to live in the vicious circle of poverty. However, even if such financial services are available, high default rate is one of the major concerns of financial institutions in less developed countries (Brehanua $\&$ Fufab 2008).

The access of capital for community based plant private forest development in Indonesia has been implemented by the government since 1980s by launching credit for farmer activity in watershed area in 1988 by the Ministry of Forestry. It was not for forest development only, but also for soil and water conservations using technical civil approach (Nugroho 2011). In 1997, loan for private forest development through credit for private forest activity were available.

Government must do its part to help alleviate our worst problems, but government alone cannot solve them (Yunus 2008). Bank leasing process is quite difficult to be implemented, meanwhile the bargaining position of forestry sector is weak. Therefore the plant forest activities are not profitable and have high risk. It causes forestry activities have less relation with the bank (Hakim 2009). In line with Hakim (2009), Nugroho (2011) stated that until today, commercial banks are not interested in providing fund for community-based forest plantations development, such as private plant forest, especially outside of Java Island, while community based forest development will potentially produce the social, economic, and environment benefits. Therefore, non-bank institutions are highly required for giving fund to this development. 
The Government of Indonesia established a public service unit called forest development funding center (pusat pembiayaan pembangunan hutan, $\mathrm{PPPH}$ ). PPPH provides loans at interest rates corresponding to those set by the Indonesian deposit insurance corporation (lembaga penjamin simpanan, LPS), which are lower than commercial rates (Obidzinski \& Dermawan 2010). PPPH is formed in 2007 to improve the people access on forestry economic activities, including its capital sector (Suhirman et al. 2012).

This condition is followed up by Ministry of Forestry Regulation Number P. 23/Menhut-II/2014 about the amendment of Ministry of Forestry Regulation Number P.36/Menhut-II/2013 about procedure of distribution and repayment of credit scheme for land and forest rehabilitation activities. It sets loan scheme payment for all development and maintenance of forest, including private forest. Especially for private forest, there is Chief of $\mathrm{PPPH}$ Regulation Number P.01/P2H/2012 about guidance of loan application for non-intermediary private forest development as the manifestation of Ministry of Forestry Regulation Number P. 36/2012.

The question of repayment of microcredit loan is one of an important questions in microfinance since the borrowers are predominantly the poor and the lower income group, where most of them are self-employed and without having any collateral assets (Roslan \& Karim 2009). The success of loan scheme should not be seen only from the improvement point of production and income, but also from how much the repayment and its implementation. This paper is aimed to find out the farmers perception on effectiveness of private forest revolving fund distribution and factors affecting its repayment.

\section{Methods}

The research was conducted during SeptemberDecember 2014 in South Lampung District, Lampung Province. This location was selected as research location because it got the biggest private forest revolving fund among the other districts in Lampung Province (PPPH 2014).

The private forest farmer group (PFFG) in Katibung SubDistrict, South Lampung District was selected as sample because the acceptance rate of PFFG members on private forest revolving fund is quite good. The household surveys were conducted for 32 households. There were 3 of 4 PFFG was selected as pilot groups. They were PFFG of Cocok Tanam in Karya Tunggal Village (12 of 14 members), PFFG Bina Tani in Karya Tunggal Village (11 of 12 members), and PFFG of Jati Jaya II in Sidomekar Village ( 9 of 11 members).

Primary and secondary data were collected. The data was collected through household surveys and in-depth interviews. The household surveys were done using structured questionnaires that included questions related to: characteristics of the borrowers, characteristics of private forest, characteristics of loan, and household perceptions on private forest revolving fund. The characteristics of the borrowers are gender, age, level of education, number of dependents, and experience on private forest management. The private forest characteristics are private forest area, income from private forest, and income from non-private forest. The characteristics of loan are amount of loan and length of repayment period. Household perceptions on private forest revolving fund are pre requirement, loan procedure, loan realization, interest rate, length of repayment periode, and repayment procedure.

Meanwhile, performance of private forest revolving fund in Lampung Province and South Lampung District were informed by PPPH. This was the secondary data.

Qualitative data which was the respondent evaluation on private forest revolving fund distribution was obtained through quantitative calculation by using the effectiveness evaluation scoring point. The determine score on the variable was appropriated with respondent understanding rate. The farmers' perception about effectiveness of private forest revolving fund distribution was analyzed by likert scale (Singarimbun \& Effendi 1995). Score 3 was given to the answer that supported this effectiveness, and score 1 for the contra answer. From the total score, the scale of loan distribution effectiveness was made up. The scaling was determined from the delta of the highest score that could be divided by the total number of question as shown in Equation [1].

Scale $=\frac{\text { Total maximum score }}{\text { Number of question }}-1$

The score of effectiveness on private forest revolving fund distribution was determined from the scale. The three scores between the possible minimum and maximum total score were divided into three effectiveness scale. The lowest scale meant that the private forest revolving fund effectiveness was low and the highest scale meant that it was effective.

Factors affecting on repayment of loan was analyzed by logistic regression. Logistic regression is a common modeling technique that classifies between two groups using a set of predictor variables (Akkoc 2012). Logistic regression is a predictive model widely used in classification (Bekhet \& Elether 2014). According to Thomas (2000), logistic regression is a linear regression in which the target variable is a non-linear function of the probability of being good. In addition, he stressed that the classification results of logistic regression model are sensitive to correlations between the independent variables. Therefore, variables used in developing the model should not be strongly correlated. The logistic regression models represented as as shown in Equation [2].

$$
\begin{aligned}
& \ln \left[\frac{Y_{i}}{\left(1-Y_{i}\right)}\right]=Z_{i}=\beta_{0}+\beta_{1} X_{i 1}+\ldots .+\beta_{k} X_{i k}+\varepsilon_{i} ; i=1,2, \ldots, n \\
& P\left(\mathrm{Y}_{\mathrm{i}}\right)=\frac{e^{Z_{i}}}{1+e^{Z_{i}}} \\
& P\left(\mathrm{Y}_{\mathrm{i}}\right)=1 \text {, probability of repayment of loan } \\
& \beta_{0}=\text { the intercept } \\
& \beta_{\mathrm{j}} \quad=1, \ldots, 12 \\
& \mathrm{X}_{\mathrm{i} 1} \quad=\text { gender } \\
& X_{i 2} \quad=\text { age (year) } \\
& \mathrm{X}_{\mathrm{i} 3} \quad \text { = level of education (year) } \\
& \mathrm{X}_{\mathrm{i} 4} \quad=\text { number of dependents (person) }
\end{aligned}
$$


$\mathrm{X}_{\mathrm{i5}} \quad=$ experience in private forest management (year)

$\mathrm{X}_{\mathrm{i} 6} \quad$ = income from private forest (IDR)

$\mathrm{X}_{\mathrm{i} 7} \quad$ income from non-private forest (IDR)

$\mathrm{X}_{\mathrm{i} 8} \quad$ = frequency of counselling (amount/time)

$X_{i 9} \quad=$ frequency of supervision (amount/time)

$\mathrm{X}_{\mathrm{i} 10}$ = amount of loan (IDR)

$\mathrm{X}_{\mathrm{i} 11} \quad$ = length of repayment period (amount year ${ }^{-1}$ )

$\mathrm{X}_{\mathrm{ij}} \quad=$ predictor variables

$\varepsilon_{\mathrm{i}} \quad=$ errors' terms

To see how the regression model can be approved, the goodness of fit test, which is measured by chi square value in Hosmer and Lemeshow test, was used. The hypothesis is explained as follows:

$\mathrm{H}_{0}$ : Model is match (there is no significant differences between observation result and prediction model)

$\mathrm{H}_{1}$ : Model is not match (there is significant differences between observation result and model prediction)

$\mathrm{H}_{0}$ is refused if sig value $<0.05$.

\section{Results and Discussion}

Private forest revolving fund Revolving fund scheme that is distributed for supporting the private forest activities in Lampung Province is in line with Ministry of Forestry Regulation Number P.36/Menhut-II/2012 about The procedure of credit distribution and repayment for land and rehabilitation program. Private forest revolving fund is implemented by using the loan scheme based on Article Number 8 (a) and without intermediary institution based on Article Number 10 (a). The amount of loan scheme that is facilitated by PPPH and in line with Article Number 29 (3) is 80,000 trees multiplied by cost for each tree.

Cost for each tree for leasing and loan of the establishment and maintenance of private forest is in line with Decision Letter of Chief of PPPH Number 16/P2H$1 / 2012$. It is presented in Table 1 and Table 2 .

Private forest revolving fund distribution in Lampung Province and South Lampung District Loan scheme from PPPH for private forest in Lampung Province is distributed in 6 of available 14 districts. It is distributed to 65 farmer groups which are consisted of 1,320 persons, i.e. 34 farmer groups in South Lampung, 12 farmer groups in Tanggamus District, 11 farmer groups in Tulang Bawang District, 4 farmer groups in West Lampung District, 2 farmer groups in North Lampung District, and 2 farmer groups in East Lampung District. The average of the farmer groups members are 19 persons.

The total amount of credit application for private forest revolving fund in Lampung Province is IDR23,93,101,000.00 and IDR11,401,662,550.00 has been distributed: IDR10,521,326,950.00 in the first distribution and IDR880,335,800.00 in the second distribution. The distribution is different, starting from December 2012 to May 2014. In South Lampung District, amount of credit application is IDR $11,669,301,000.00$ and IDR 5,368,477,550.00 has been distributed: IDR5,207,284,950.00 in the first distribution and IDR161,192,600.00 in the second distribution.

From 34 farmer groups (738 persons) that obtained the

Table 1 Cost for each tree for leasing and loan of private forest establishment

\begin{tabular}{|c|c|c|c|}
\hline $\begin{array}{l}\text { Year/ } \\
\text { Number }\end{array}$ & Term of activities & for each tree (IDR) & Remark \\
\hline \multirow[t]{6}{*}{ Year I } & Term I & & \\
\hline & 1. Seedling procu rement & 5,500 & Distributed after loan agreement \\
\hline & 2. Planting & 3,550 & Distributed after loan agreement \\
\hline & Term II & & \\
\hline & 3. Replanting and maintenance of on going year & 5,225 & $\begin{array}{l}\text { Distributed after realization of Term I } \\
\text { activities }\end{array}$ \\
\hline & Total of Year I & 14,275 & \\
\hline \multirow[t]{3}{*}{ Year II } & Term III & & \\
\hline & $\begin{array}{l}\text { 4. Replanting and maintenance of Year I } \\
\text { and maintenance of Year II etc. }\end{array}$ & 5.725 & $\begin{array}{l}\text { Distributed in Year II after the realization } \\
\text { of Term II activities in Year I }\end{array}$ \\
\hline & Total amount & 20.000 & \\
\hline
\end{tabular}

Decision Letter of Chief of PPPP Number 16/P2H-1/2012

Table 2 Cost for each tree for leasing and loan of private forest maintaining

\begin{tabular}{|c|c|c|c|}
\hline $\begin{array}{l}\text { Year/ } \\
\text { Number }\end{array}$ & Term of Activities & Cost for each tree (IDR) & Remark \\
\hline \multirow[t]{2}{*}{ Year I } & Term I & & \\
\hline & 1. Maintenance I & 5,225 & Distributed after loan agreement \\
\hline \multirow[t]{3}{*}{ Year II } & Term II & & \\
\hline & 2. Maintenance II, etc. & 5,725 & $\begin{array}{l}\text { Distributed in Year II after the realization of } \\
\text { Year I activities }\end{array}$ \\
\hline & Total amount & 10,950 & \\
\hline
\end{tabular}

Decisionletter of chief of PPPP Number 16/P2H-1/2012 


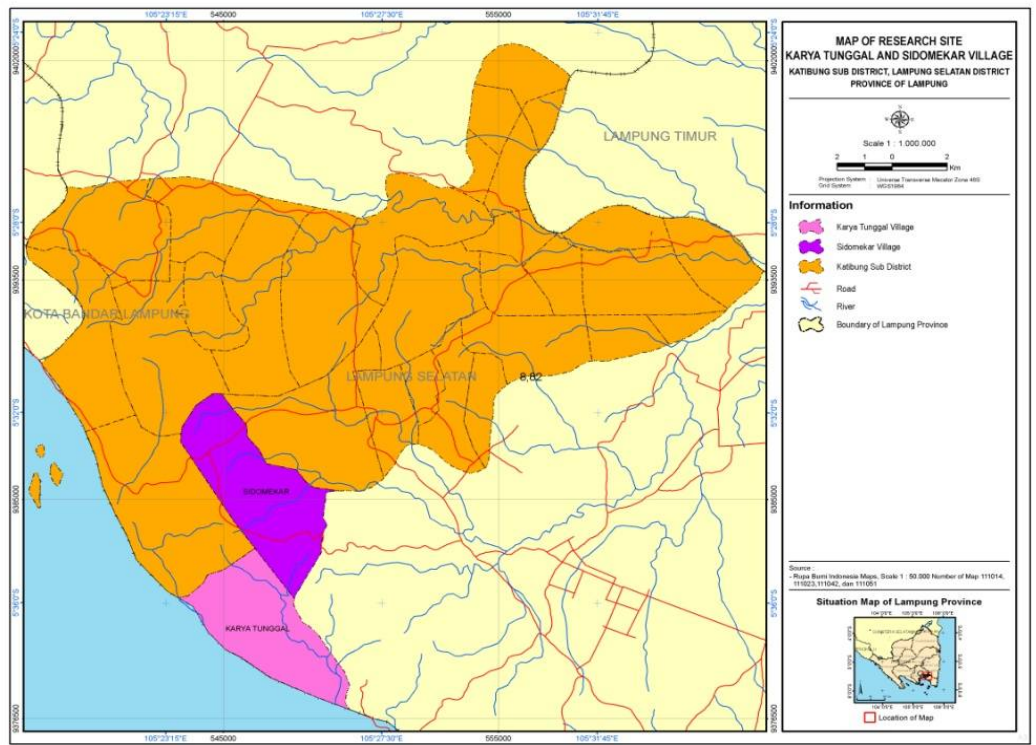

Figure 1 Map of research site.

loan scheme for private forest in South Lampung District, there were 26 farmer groups $(76.47 \%)$ that had been evaluated by PPPH on December 2014. The evaluation result showed that 380 persons $(51.5 \%)$ did not obtain the second distribution of loan scheme and they had to give the repayment plus its interest in the end of December 2014 because the realization of planted plant was less than $40 \%$.

From 380 persons that had to repay the loan scheme, there were 18 persons $(4.74 \%)$ used the loan scheme for the cut postponement of private forest and the rest for private forest establishment. However, the first debitor was not consistent in implementing the agreement with PPPH where they cut the tree before the accepted time period. Therefore, the debitor had to repayment loan scheme plus its interest.

This condition shows that loan scheme is not well implemented because the debitors are not consistent with their agreement with PPPH. Article Number 7 of Ministry of Forestry Regulation Number P. 36/Menhut-II/2012 stated those 4A principles: appropriate subject, appropriate location, appropriate activities, and appropriate distribution and repayment must be implemented in executing the loan scheme distribution. Debitor low commitment is caused by the opinion that loan scheme is a loan that has to be repaid, but if it has not smooth repayment, then one day it will be deleted as the previous experience. This wrong opinion is caused by the incomprehensive socialization.

The general condition of research location Katibung SubDistrict is located in South Lampung District. It has 21.287 ha and 12 villages. This sub-district is located in E105'14'$105^{\circ} 45^{\prime}$ and $S 5^{\circ} 15^{\prime}-6^{\circ}$. Most of Katibung Sub-District's topography is plain area with $50.3 \mathrm{~m}$ below sea level of average of height. It is about $82.15 \%$ of Katibung's land becomes plantations and farms (BPS of Lampung Selatan Regency 2015).

In 2014 , there were 64,388 people in Katibung SubDistrict. It was consisted of 33,160 males and 31,228 females. The people's density rate was 302.48 persons $\mathrm{km}^{-2}$.
The average of people's education duration was 6.87 years or equal to the sixth grade of primary school (BPS of Lampung Selatan Regency 2015).

In 2014, there were 2,676 people in Karya Tunggal Village. It was consisted of 1,404 males and 1,272 females. It had 1,658.5 ha of village area. The people's density rate was 161.3 persons $\mathrm{km}^{-2}$. Meanwhile, Sidomekar Village had 700 ha of village area and 2,602 persons. It was consisted of 1,320 males and 1,282 females. It had 371.71 persons $\mathrm{km}^{-2}$ of people's density rate (BPS of Lampung Selatan Regency 2015).

Characteristics of respondents The goal of a microcredit program transcends the business oriented aspects of investment and specifically targets improved livelihoods for loan recipients (Yunus 2007). In order to achieve livelihood improvement, the household characteristics and borrowing behaviours of target groups need to be well understood (Nugroho et al. 2013). The results of household surveys conducted bring insights on these characteristics and behaviour summarized below.

The respondents was dominated by males $(87.5 \%)$ and it was about $96.9 \%$ of respondents was in productive age (15-65 years old). Most of respondents $(65.6 \%)$ was junior and senior high school graduated. They $(87.5 \%)$ were in small liabilities category (1-3 persons). For about $62.5 \%$ respondents had more than 10 years' experience in private forest sector.

In this 2 villages, most of respondents $(53.1 \%)$ obtained less than IDR1,500,000 month ${ }^{-1}$ of income from private forest. Most of respondents (57\%) took private forest as their main job, while the rest took it as side job. The total of income that was obtained from private forest and income from nonprivate forest, such as civil servant, palm plantation, trader, etc., the total was more than IDR3,000,000 month $^{-1}$.

The revolving fund that was proposed by the respondents would be based on their private forest land area and the prediction of respondents' income for its repayment. Most of 
revolving fund was IDR15,000,000-IDR30,000,000 with 6 years of repayment duration, based on the tree species (sengon) harvesting time.

The conditions of private forest management Nugroho (2010) wrote that the characteristic of private forest management, generally, is consisted of management, product, and marketing aspects. The characteristics of private forest management in study location can be explained as follows

\section{Characteristic of management}

Private forest management was conducted by household workers, i.e. father/mother/children as worker and the manager as well. Private forest management did not require intensive care and much time. The average of respondents' working time was 3.7 hours a day. The remaining time was used for the other job, such as farming labor, trader, and so on. Decision to harvest the private forest product was based on family's needs.

2 Characteristic of product

The area was household private garden that combined the forestry plants and farming plants (agroforestry). The average of land ownership was 1.11 ha. People in study location chose banana as priority plantation to obtain main income. Beside banana, there were chocolate, coconut, fruits such as durian, lanseh, candlenut, petai, jengkol, and woods.

Village land condition was dominated by hilly topography $(80 \%)$. It made people plant tree species, such as sengon (Paraserianthes falcataria), akasia (Acacia mangium), and jabon (Anthocephalus cadamba). Some farmers that planted tree for investment were usually having well established economy. Some considerations of farmers in choosing sengon as dominant tree species were: its short harvesting time (5 years) than the others; easy seedling procurement (bought from the seller or made the natural seedling), and easy in marketing process.

3 Characteristic of marketing

Banana as the non-wood product can be used for fulfilling the daily needs. All the respondents planted banana in their private forest. The existence of banana traders (more than 10 persons) in village made the farmers sell their products easily. The greater trader took the bananas from the village traders almost every day. They sold it to outside of Lampung (Jakarta) directly.

In general, the private forest product, especially wood, was conducted in small amount and stands based (one or several trees) and used wholesale system. It was chosen because its practice. Farmers sold their woods to the trader. Farmer directly sold it to the final customer rarely. There were also people who did not sell their wood from their private forest, but used it for fulfilling their needs (house/building).

The farmers perception on the effectiveness of private forest revolving fund The evaluation on loan scheme can be seen from the argument of many factors, such as pre requirement for obtaining loan scheme, loan procedure, loan realization, collateral, interest rate, length of repayment period, and loan procedure as below.
1 Pre requirement

Private forest revolving fund is aimed for strengthening capital of private forest establishment activities. Therefore, it is a stimulator based on Article Number 3 of Ministry of Forestry Regulation Number P.36/2012. Based on the previous experience about the loan for private forest establishment, such as the credit for farmer activity in watershed area and credit for private forest activity that produce more problems with its high not payable loan, it makes the PPPH to arrange the pre requirement for loan scheme, starting from its application to its realization that the requirement is easy to be fulfilled but it's still keep safety principals according to Article Number 2 of Ministry of Forestry Regulation Number P.36/2012.

The farmers perception in fulfilling the pre requirement was easy. Respondents usually fulfilled the pre requirement collectively through group's officer by paying some money to make it easier and more practice. Meanwhile, respondents which stated that the pre requirement was difficult, the persons who fulfilled the requirement by themselves, such as a letter of land ownership that was launched by the chief of village.

2 Loan procedure

The steps in loan procedure are quite easy. The farmers through its farmer group (debitors), by PPPH facilitation and guidance, send the application to the Chief of PPPH by attaching the proposal (Article Number 33 of Ministry of Forestry Regulation Number P.36/2012). Next, the Chief of PPPH will evaluate the proposal based on the guidance of proposal evaluation, and then send the team from the central office or the extension officer to execute the field verification and clarification, which is related to the land physical condition, economic and social condition, and so on.

If the result is fulfilled the evaluation criteria, the Chief of PPPH will give the principal agreement which will be followed up by the loan offer and the decision of loan distribution to be delivered the applicant. If the applicant accept this offer, next the applicant sign the offer to be delivered to the Chief of PPPH as a base in launching loan distribution. The farmers have perception that procedure of loan was easy.

3 Loan realization

Based on the standard of PPPH, it requires 2-4 month to process the credit starting from application making until its field verification and loan distribution. The applied loan has to appropriate with the result of field verification and distribute to the debitors through the overbooking from the account of the Chief PPPH to the account of loan receiver. Therefore the debitors must have the account in certain bank in the list of PPPP. BRI is one of these.

Private forest loan is distributed in some terms because of some considerations, i.e. technical aspect of its business, the debitor's ability in repayment the loan and loan continuing and balancing aspects of private forest loan distribution term (Article Number 13 (2) of $\mathrm{MoF}$ Regulation Number P.36/2012)

The first term of loan distribution is conducted after signing the agreement and confirming the requirements 
of loan agreement. The next distribution will be conducted based on the evaluation on working of loan debitors that will be executed by the PPPH or the third party (Article Number 34 of Ministry of Forestry Regulation Number P.36/2012). If their performance is not appropriate with its agreement, the Chief of PPPP has a right to postpone or stop the next term loan distribution and so the contrary.

The farmers have perception that loan realization was fast. The third respondents said so because loan distribution was not in line with season time where the rainy season for planting season will end soon so that it can reduce the probability of planted tree grow.

\section{Collateral}

Based on Article Number 15 (1e) of Ministry of Forestry Regulation Number P. 36/Menhut-II/2012, the collateral guarantee for individual private forest manager is tree stand or land ownership documents or land management right for individual private forest manager. The farmers have perception that collateral was easy to be fulfilled. This easy guarantee is expected to be able to improve the commitment of debitors to use loan as its allocation, which is for private forest establishment activities.

5 Interest rate

Based on Article Number 17 of Ministry of Forestry Regulation Number P. 36/2012, the loan interest rate is proposed by the minister to the minister of monetary in proposal of loan cost as a base of cost determination by the minister of monetary. This proposed interest considers many factors i.e. purchasing power or the ability of the debitors in rapayment the loan, loan service implementation, business competition, and fairness.

PPPP determined that the available interest rate was in line with the interest rate of Bank of Indonesia, i.e. 7.75\% per year and flat. This interest rate was much lower than the conventional bank's interest rate, i.e. $8,66 \%-22,56 \%$ per year (Bank of Indonesia 2014). The farmers have perception that interest rate of loan was low.

Other key causes of delinquency are the rate of interest and the loan size. High interest rates significantly increase the odds of client delinquency while loan size is inversely related to delinquency (Kodongo \& Kendi 2013).

\section{Length of repayment period}

The maximum length of repayment period was 8 years (Article Number 28 of Ministry of Forestry Regulation Number P. 36/2012). Meanwhile, most of the debitors took 6 years for loan duration. It was match with the harvesting time. The planted tree was dominated by sengon (Paraserianthe falcataria), jabon (Anthocephalus cadamba), and akasia (Acacia mangium) and due to the filed bio-physical condition. Sengon could be harvested through selected cuttting or clear cutting in 6 years. Moreover, it could be harvested in 3-4 years through in-between harvesting time through the rouging activities. The ability of farmers to repayment the loan depend on their income.

7 Procedure of repayment
Debitors have to repayment their loan based on the procedure in the agreement though the overbooking from the debitors account to loan distributor's account. If they were not able to do this, the Chief of PPPP would foreclose the collateral and they could do this by hiring the third party. Repayment was implemented in the end of the harvesting time and it paid all at once with its interest. The farmers have perception that the repayment was easy.

The obtained score from the respondents was used to see whether loan service from PPPP was quite effective based on the debtor's opinion or not. The respondent's score was 612 , while the minimum score was 224 and the maximum was 672, with Likert Scale calculation in scale 148.3. Based on this calculation, the effectiveness scale could be as follow: score 224-372.3 was not effective, 373.3-521.6 was quite effective, and 522.6-672 was effective.

The effectiveness of debitors distribution would be higher if the respondent said that the loan scheme pre requirement was easy, the loan procedure was easy, the loan realization was fast, having low interest rate, easy collateral, long repayment duration, and easy repayment procedure. Based on the respondent, private forest revolving fund service from PPPP was effective as shown in Table 3 .

From Table 3 it can be seen that based on the respondent, the loan realization factor (score 78) is the most difficult factor than others that influencing the effectiveness of private forest revolving fund distribution. Meanwhile, the assurance and loan duration becomes the easiest factors for the farmers (score 92). Microcredit can only be effective if it is judiciously used to ensure that both the lender and the borrower reap the maximum possible gain (Kodongo \&Kendi 2013).

Factors affecting repayment of private forest revolving fund There are 8 independent variables influencing the identified revolving fund based on theoretical study on model, i.e. gender $\left(\mathrm{X}_{1}\right)$, age $\left(\mathrm{X}_{2}\right)$, level of education $\left(\mathrm{X}_{3}\right)$, number of dependents $\left(\mathrm{X}_{4}\right)$, experience on private forest management $\left(\mathrm{X}_{5}\right)$, income from private forest $\left(\mathrm{X}_{6}\right)$, income of non-private forest $\left(\mathrm{X}_{7}\right)$, and amount of loan $\left(\mathrm{X}_{8}\right)$. Model analysis is conducted to see the multi-colinearity among independent variables. The multi-colinearity test shows that there is no multi-colinearity in model's variables.

Based on table of Hosmer and Lameshow test, chi-square values showed 1.953 with a significance value of 0.982 (> 0.05). This means that model is suitable and acceptable. The value of Cox and Snell R and R Nagelkerke Square was used to see capability of independent variables in explaining accuracy of predicting factors. The result test showed that independent variables in this study were able to explain probability of repayment loan as many as $69.3 \%$.

Result of logistic regression (Table 5) shows that significant level of $\mathrm{X}_{7}$ (income of non-private forest) is 0.082 and 0.068 for $\mathrm{X}_{8}$ (amount of loan). Due to those value is less than 0.1 ( $90 \%$ of significant level), the variables of income of non-private forest sector and total of loan give significant influence on opportunity of revolving fund repayment. Odd Ratio value (1.00) shown in the table means that 1 unit 
Tabel 3 Characteristic respondent

\begin{tabular}{|c|c|c|}
\hline Characteristic & $\mathrm{n}$ & $(\%)$ \\
\hline \multicolumn{3}{|l|}{ Gender } \\
\hline Male & 28 & 87,5 \\
\hline Female & 4 & 12,5 \\
\hline Total & 32 & 100 \\
\hline \multicolumn{3}{|l|}{ Age (year) } \\
\hline $15-65$ & 31 & 96,9 \\
\hline$>65$ & 1 & 3,1 \\
\hline Total & 32 & 100 \\
\hline \multicolumn{3}{|l|}{ Level of education } \\
\hline No schooling-elementary & 10 & 31,3 \\
\hline Junior-Senior High School & 21 & 65,6 \\
\hline Diploma/Sarjana & 1 & 3,1 \\
\hline Total & 32 & 100 \\
\hline \multicolumn{3}{|l|}{ Number of dependents (person) } \\
\hline $1-3$ & 28 & 87,5 \\
\hline $4-5$ & 4 & 12,5 \\
\hline$>5$ & 0 & 0 \\
\hline Total & 32 & 100 \\
\hline \multicolumn{3}{|l|}{ Experience of private forest management (year) } \\
\hline $0-5$ & 4 & 12,5 \\
\hline $6-10$ & 8 & 25 \\
\hline$>10$ & 20 & 62,5 \\
\hline Total & 32 & 100 \\
\hline \multicolumn{3}{|l|}{ Income from private forest month $^{-1}(\times$ IDR million $)$} \\
\hline$<1,5$ & 17 & 53,1 \\
\hline $1,5-3$ & 10 & 31,3 \\
\hline$>3$ & 5 & 15,6 \\
\hline Total & 32 & 100 \\
\hline \multicolumn{3}{|c|}{ Income from non-private forest/month $(\times$ IDR million $)$} \\
\hline$<1,5$ & 23 & 71,9 \\
\hline $1,5-3$ & 5 & 15,6 \\
\hline$>3$ & 4 & 12,5 \\
\hline Total & 32 & 100 \\
\hline \multicolumn{3}{|l|}{ Income total $/$ month $(\times$ IDR million $)$} \\
\hline$<1,5$ & 2 & 6,25 \\
\hline $1,5-3$ & 11 & 34,4 \\
\hline$>3$ & 19 & 59,4 \\
\hline Total & 32 & 100 \\
\hline \multicolumn{3}{|l|}{ Amount of loan $(\times$ IDR million $)$} \\
\hline$<15$ & 11 & 34,4 \\
\hline $15-30$ & 18 & 56,3 \\
\hline$>30$ & 3 & 9,3 \\
\hline Total & 32 & 100 \\
\hline \multicolumn{3}{|l|}{ Length of repayment period (year) } \\
\hline $0-5$ & 0 & 0 \\
\hline $4-5$ & 0 & 0 \\
\hline$>6$ & 32 & 100 \\
\hline Total & 32 & 100 \\
\hline
\end{tabular}

increase on income of non-private forest and revolving fund loan can increase the opportunity of revolving fund repayment without arrear for 1 time.

More total of loan makes more opportunity in revolving fund repayment. Smaller loan is predicted will not enough in finishing borrower's financial problem. When proposing total of loan, debtor has predicted its repayment. All this time, the respondents have income from non-private forest, such as oil palm plantation, civil servants, trader, and other services that is greater than income from private forest.

Schreiner (2003) studied cost-effectiveness analysis of the Grameen Bank of Bangladesh. He found that joint liability reduces risk as members have knowledge of individual character and can screen potential borrowers. 
Table 4 Result of scorring on evaluation and effectiveness of loan scheme distribution

\begin{tabular}{lccc}
\hline \multicolumn{1}{c}{ Parameter } & Score & Maximum score & Percentage (\%) \\
\hline Pre requirement & 87 & 96 & 90.6 \\
Loan procedure & 89 & 96 & 93.8 \\
CFL realization & 78 & 96 & 81.3 \\
Assurance & 92 & 96 & 95.8 \\
Interest rate & 90 & 96 & 93.8 \\
Loan duration & 92 & 96 & 95.8 \\
Repayment procedure & 84 & 96 & 87.5 \\
\hline \multicolumn{1}{c}{ Total } & 612 & 672 & 91.1 \\
\hline
\end{tabular}

Tabel 5 Result of logistic regression analysis

\begin{tabular}{|c|c|c|c|c|c|c|c|}
\hline & & B & S.E. & Wald & Df & Sig. & $\operatorname{Exp}(B)$ \\
\hline \multirow{9}{*}{ Step $1^{\mathrm{a}}$} & gender & -.408 & 2.180 & .035 & 1 & .852 & .665 \\
\hline & age & -.141 & .149 & .899 & 1 & .343 & .868 \\
\hline & $\begin{array}{l}\text { education } \\
\text { level }\end{array}$ & -1.100 & .785 & 1.964 & 1 & .161 & .333 \\
\hline & $\begin{array}{l}\text { number of } \\
\text { dependents }\end{array}$ & -1.257 & 1.716 & .537 & 1 & .464 & .285 \\
\hline & $\begin{array}{l}\text { experience on } \\
\text { private forest }\end{array}$ & -.197 & .262 & .563 & 1 & .453 & .822 \\
\hline & $\begin{array}{l}\text { income from } \\
\text { private forest }\end{array}$ & .000 & .000 & 2.700 & 1 & .100 & 2.762 \\
\hline & $\begin{array}{l}\text { Income from } \\
\text { non-private } \\
\text { forest }\end{array}$ & .000 & .000 & 3.030 & 1 & .082 & 2.782 \\
\hline & jml_pinjaman & .000 & .000 & 3.319 & 1 & .068 & 3.294 \\
\hline & Constant & 11.564 & 8.209 & 1.984 & 1 & .159 & 105266.842 \\
\hline
\end{tabular}

Variable(s) entered on step 1: gender, age, education level, number of dependents, experiecne of private forest, income from private forest, income from non-private forest, amount of loan.

Through peer pressure members mentor each other and can coax comrades out of arrears or even to repay their debts for them.

There was a need to improve private forest revolving fund scheme, including the basis of loan calculation, credit rationing, the target group, the credit ceiling, and the payment system (Nugroho 2010). Group lending programs may also rely on social sanctions and non refinancing threats to induce prompt repayment among borrowers (Okten \& Osili 2004; Brehanua \& Fufab 2008). Group lending has been used successfully in some parts of the world (notably by the Grameen Bank) to expand the reach of microcredit programs. Clearly, group lending appears to command an edge over individual lending in mitigating loan default (Kodongo \& Kendi 2013). However, whether group lending improves loan repayment or not is still controversial (Huppi \& Feder 1990; Zeller 1998).

A host of factors related to socioeconomic and institutional characteristics of the households could explain the differences in the rate of default on borrowed funds. Identifying those factors that are critical determinants of rate of repayment of loans is important for the design and implementation of lending policies aimed at improving default risks (Brehanua \& Fufab 2008).

The faced problems and its solutions Some faced problems in private forest revolving fund implementation are:

1 Brokering

The private forest revolving fund socialization in South Lampung District was directly conducted by the minister of forestry. A certain party, who said that he/she could help the private forest farmer group (PFFG) in obtaining the loan scheme from PPPH by asking some money for application making, came to the 3 chairmen of PFFG. When the application was accepted by PPPP, he/she played a role as a seller of PFFG required seedlings.

2 Discrepancy of information

The farmers/debitors obtained the information about loan scheme from certain persons. However, the information was inconsistent. As the field extensions of PPPP came, this was not become a problem any longer. But the field extensions was considered as the obstacles for certain parties who would like to take that opportunity, so that it caused the field conflict and made the extension 
officers felt uncomfortable in doing their job in assisting and facilitating the PFFG.

3 The implementation of 4A in loan distribution

Based on Ministry of Forestry Regulation Number P. 36/Menhut-II/2012, the loan distribution implements the 4A principals (appropriate subject, appropriate location, appropriate activities, and appropriate distribution and repayment). From the interview result, there were a lot of debtors that have wide land area and were economically settled and receiving loan. According to the appropriate subject principal, they were not appropriate to become loan debitors because they do not need the private forest revolving fund. The chairmen of farmer group and the debitors stated that one of the reasons why did the debitors with above characteristic exist; it was because the debitors want to have support from such debtors who were the public figure and rich people.

These 4A principals were one of strategy to avoid the loan failure, i.e. conducted the selection for the debtors candidate that covering the characteristic of debtor candidate and their business. The consequence was the PPPP would conduct selection through information collection that related to the debtor candidates with high cost and it related to screening problem as well. The existing of field officers could reduce the above emerged problems, because they could give any information correctly to the farmers. In the other hand, the PPPP could get appropriate information about the debitor candidates through the field extensions.

Based on institutional perspective, some principles that should be followed to support the poor to access the credit were simplicity, accessibility, conformity, feasibility, sustainability, transparancy, supervisory, assisting and facilitating, and learning (Nugroho 2010). The success of microlending programs among the poor may lie in a diverse set of mechanisms including joint liability, peer monitoring, contingent renewal, as well as social cohesion among group members (Ghatak 1999; Ghatak \& Guinnane 1999).

\section{Conclusion}

Based on the perception of farmers on private forest revolving fund distribution, it could be concluded that private forest revolving fund distribution was effective. Income from non-private forest and amount of loan are factors affecting on repayment of private forest revolving fund. The faced problems in revolving fund distribution can be solved by maximizing the role of field extensions of Forest Development Funding Center PPPH in assisting and facilitating the private forest revolving fund debitors candidates.

\section{References}

Akkoc S. 2012. An empirical comparison of conventional techniques, neural networks and the three stage hybrid adaptive neuro fuzzy inference system (ANFIS) model for credit scoring analysis: The case of Turkish Credit Carddata. European Journal Operation Research 222:168-178. http://dx.doi.org/10.1016/j.ejor.2012.
04.009

Bank of Indonesia. 2014. Suku Bunga, Diskonto, dan Imbalan per September 2014. http://www.bi.go.id/ $\mathrm{id} /$ statistik/seki/terkini/moneter/Contents/Default.aspx.

Bekhet HA, Eletter SFK. 2014. Credit risk assessment model for Jordanian commercial banks: neuralscoring approach. Review of Development Finance 4(1):20-28. http://dx.doi.org/10.1016/j.rdf.2014.03.002.

[BPS] Badan Pusat Statistik of Lampung Selatan Regency. 2015. Katibung Sub-District in Figures 2015. Kalianda: BPS of Lampung Selatan Regency.

Brehanua A, Fufab B. 2008. Repayment rate of loans from semi-formal financial institutions among small-scale farmers in Ethiopia: Two-limit Tobit analysis. The Journal of Socio-Economics 37: 2221-2230. http://dx. doi.org/10.1016/j.socec.2008.02.003.

Decision Letter of Chief of PPPP Number 16/P2H-1/2012.

Ghatak M. 1999. Group lending, local information and peer selection. Journal of Development Economics 60(1):27-50. http://dx.doi.org/10.1016/S03043878(99)00035-8.

Ghatak M, Guinnane TW. 1999. The economics of lending with joint liability: Theory and practice. Journal of Development Economics 60(1):195-228. http://dx.doi.org/10.1016/S0304-3878(99)00041-3.

Green DAG, Ng'ong'ola DH. 1993. Factors affecting fertilizer adoption in less developed countries: An application of multivariate logistic analysis in Malawi. Journal of Agricultural Economics 1:99-109. http://dx.doi.org/10.1111/j.1477-9552.1993.tb00253.x

Hakim I. 2009. Review on Institution and policy of community plantation forest: A breaktrough towards restructuring the concept of sustainable forest management. Jurnal Analisis Kebijakan Kehutanan $6(1): 27-41$.

Huppi M, Feder G. 1990. The role of groups and credit cooperatives in rural lending. World Bank Research Observer 5:187-204. http://dx.doi.org/10.1093/wbro 15.2.187.

Kodongo O, Kendi LG. 2013. Individual lending versus group lending: An evaluation with Kenya's microfinance Data. Review of Development Finance 3: 99-108. http://dx.doi.org/10.1016/j.rdf.2013.05.001.

[MoF] Ministry of Forestry. 2013. Regulation Number P.36/Menhut-II/2013 about Procedure of Distribution and Repayment of Credit Scheme for Land and Forest Rehabilitation Activities. Jakarta: Ministry of Forestry.

[MoF] Ministry of Forestry. 2014. Regulation Number P. 23/Menhut-II/2014 about The Amendment of Ministry of Forestry Regulation Number P.36/Menhut-II/2013 about 
Procedure of Distribution and Repayment of Credit Scheme for Land and Forest Rehabilitation Activities. Jakarta: Ministry of Forestry.

Nugroho B. 2010. Institutional development for community forest revolving fund. Jurnal Manajemen Hutan Tropika 16(3):118-125.

Nugroho B. 2011. Comparative analysis of credit schemes for community-based forest plantation in Indonesia. Jurnal Manajemen Hutan Tropika. 17(2):79-88.

Nugroho B, Dermawan A, Putze L. 2013. Financing smallholder timber planting in Indonesia: Mismatches between loan scheme attributes and smallholder borrowing characteristics. International Forestry Review 15(4): 499-508.

Obidzinski K, Dermawan A. 2010. Smallholder timber plantation development in Indonesia: What is preventing progress? International Forestry Review 12(4):339-348. http://dx.doi.org/10.1505/ifor.12.4.339.

Okten C, Osili UO. 2004. Social networks and credit access in Indonesia. World Development 32(7):1225-1246. http://dx.doi.org/10.1016/j.worlddev.2004.01.012.

[PPPH] Pusat Pembiayaan Pembangunan Hutan. 2014. Distribution of Private Forest Revolving Fund in Lampung Province. Jakarta: PPPH.

Roslan AH, Karim MZA. 2009. Determinant of microcredit repayment in Malaysia: The case of agrobank. Humanity and Social Sciences Journal 4(1):45-52.

Schreiner, M. 2003. A Cost-Effectiveness Analysis of the Grameen Bank of Bangladesh. Bangladesh: St. Louis Publishers.
Shakya PB, Flinn JC. 1985. Adoption of modern varieties and fertilizer use on rice in the Eastern Terri of Nepal. Journal of Agricultural Economics 36:409-419. http://dx.doi.org/10.1111/j.1477-9552.1985.tb00188.x.

Singarimbun M, Effendi S. 1995. Metode Penelitian Survai. Jakarta: LP3ES.

Suhirman Z, Alamsyah AZ, Sulaiman, Nikoyan A. 2012. Studi Perencanaan \& Penganggaran bagi Pengelolaan Hutan berbasis Masyarakat di Indonesia: Studi Kasus Provinsi Jambi, Kalimantan Barat, Nusa Tenggara Barat, Sulawesi Tenggara. Laporan utama sebagai hasil studi lapangan. Jakarta: Kemitraan (Bagi Pembaruan Tata Kepemerintahan di Indonesia).

Thomas L. 2000. A survey of credit and behavioral scoring: Forecasting financial risk of lending to consumers. International Journal Forecast16:149-72. http://dx.doi.org/10.1016/S0169-2070(00)00034-0.

Yunus M. 2007. Bank Kaum Miskin: Kisah Yunus dan Grameen Bank Memerangi Kemiskinan. Nasution I, translator. Translated from: Banker to The Poor: Microlending and The Battle Against World Poverty. Depok: Marjin Kiri.

Yunus M. 2008. Creating a world without poverty: Social business and the future of capitalism. Global Urban Development 4(2):1-19.

Zeller M. 1996. Determinants of Repayment Performance in Credit Groups: The Role of Program Design, Intra group Risk Polling and Social Cohesion in Madagascar. FCND Discussion Paper No 13. Food Consumption and Nutrition Division. Washington: International Food Policy Research Institute. 